\title{
Effect of Multi-Row Intercropping on the Severity of Chickpea Ascochyta Blight
}

\author{
Qasim Abdulla Marzani ${ }^{1}$, Azhen Mohammad Hassan ${ }^{2}$, \\ Dleen Naji Abdulrahman ${ }^{3}$ \\ (Department of Plant Protection, College of Agriculture, University of Saladin, Erbil, Southern Region of \\ Kurdistan-Iraq)
}

\begin{abstract}
Chickpea blight severity caused by Ascochyta rabiei, was evaluated by planting chickpea intercropping with three other crops namely wheat, faba bean, and oilseed rape in a randomized complete block design (RCBD) with three replications. Following winter sowing, the chickpea crop cultivar IPA-510 planted in Erbil region in the beginning of January. The results showed that the combination of these crops with chickpea affected significantly on the diseases incidence. The lowest degree of infection was with combinations of chickpea with faba bean followed by combination of chickpea with the oilseed rape then chickpea with wheat compared with the control treatment (monocrop). However, this intercropping system didn't have significant effects on the percentage of pod infection and weight of 100 seed. Intercropping chickpea with companion crops showed that both oilseed rape and faba bean didn't affect on the seed yield. However, wheat as a companion crop with chickpea, is decreased the chickpea yield.
\end{abstract}

Keywords: chickpea, ascochyta blight, Ascochyta rabiei, intercropping.

\section{Introduction}

Under Mediterranean growing conditions, Ascochyta rabiei (Pass.) Labrouse causes severe blight epidemics on chickpea (Cicer arietinum L.), particularly when sowing is done during winter [1]. Management of ascochyta blight is normally achieved with the use of fungicides and grow of resistant cultivars. Several protective fungicides have been identified but chemical control is neither practical nor commercial, because more than six fungicide applications per season are required to control the disease in susceptible cultivars [2]. Development of cultivars with resistant to ascochyta blight is also not easy to do due to lack of higher and stable resistance [3].

Intercropping, the simultaneous cultivation, is a cropping technology which may be useful for more efficient use of resources, more stable yields in problematic environment and a method to reduce problems with weeds, plant pathogens and nitrogen losses post grain legume harvest [4]. Intercropping or companion cropping is an alternate to mono-cropping or single cropping. Intercropping is the growing of two or more crops in proximity to promote interaction between them. This system of growing crops together can reduce the use of pesticides and herbicides, increase the yield of an existing cash crop, and better utilize of resources such as water, light, and nutrients. Intercropping chickpea with wheat where their roots intermingled resulted in more uptake and concentration of phosphorous in wheat [5]. Growing barley as a companion crop with pea always reduced foliar ascochyta blight (Mycosphaerellla pinodes) levels by $40 \%$ [6].

The growing system technique, intercropping, was so successful in Yunnan province in china at reducing blast disease to a degree that the farmers were able to abandon chemical fungicides they had been using [7]. The lowest population of root knot nematode was recovered from chickpea intercropped with mustard and the highest population was recovered in the sole chickpea [8]. Because the disease ascochyta blight of chickpea is epidemic in Hawler province of Southern region of Kurdistan [9], this work aims to determine the effects of multi-row intercropping on the severity of chickpea blight in the field.

\section{Materials And Methods}

The experiment was conducted in the fields belong to the College of Agriculture (Girdarasha fields about $4 \mathrm{~km}$ south of Hawler). A moderate susceptible chickpea cultivar, IPA-510, which obtained from IPA centre for agricultural researchs, Mosul, was planted as a base crop intercropped with wheat (Tritichum aestivum L.), broad bean (Viciae vapae L.) and oilseed rape (Brassica napus L.). Sole chickpea (as a monocrop) was grown as a control treatment. The cultivars selected for each crop included in the system were Aksad-65 (wheat), Pactol (oilseed rape), and Holland (faba bean). Each treatment was replicated three times. The twelve rows in each plot where for chickpea grown in three rows alternated with three rows of companion crops wheat, oilseed rape and broad bean (Figure 1). The field experiment was designed to a randomized complete block design (RCBD) in which seed was drilled in $30 \mathrm{~cm}$ spaced rows (the distance between rows) for chickpea, 
oilseed rape, broad bean and wheat, while the plant-to-plant distances (the distance between seeds) was $10 \mathrm{~cm}$ for chickpea and wheat, $20 \mathrm{~cm}$ for broad bean and $20 \mathrm{~cm}$ for oilseed was maintained by thinning ten days after germination. The net plot size of the experiment was $2 \times 3.7 \mathrm{~m}$ in a rate 12 rows per plot for each two crops in a plot.
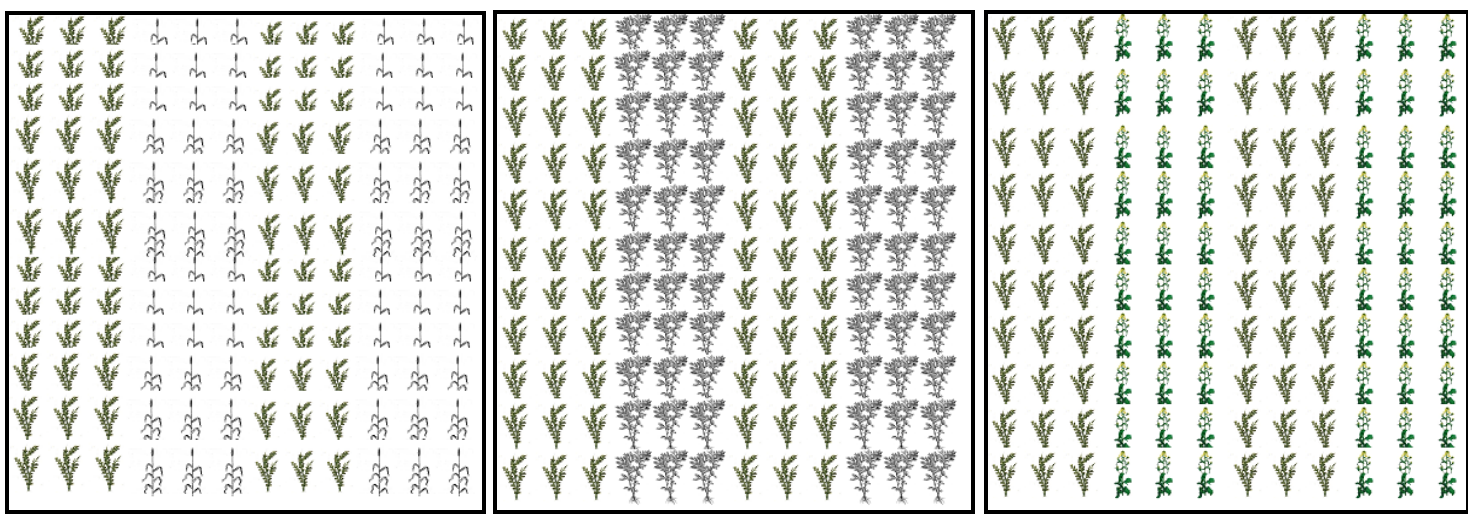

Figure 1 The diagram showing chickpea intercropping with wheat (left), faba bean (middle), and with oilseed rape (right).

To inoculate chickpea plants with ascochyta blight disease, infected chickpea residue from last year was spread on the plots in the rate of $50 \mathrm{~g} / \mathrm{plot}$. The disease occurrence on the chickpea plants was monitored and when the disease development was checked just before crop mature, the severity of infection, percentage of pod infection and weight of 100 seed were measured by taking 5 plants in each row ( 15 plants/treatment) by using $0-5$ evaluation scale [10] which modified from $0-4$ evaluation scale established by [11] as follows:

$0=$ no visible lesions.

$1=\mathrm{a}$ few small (up to $5 \mathrm{~mm}^{2}$ ) lesions on stem and/or foliage.

$2=$ superficial stem lesions exceeding $5 \mathrm{~mm}^{2}$ and absence of stem girdling.

$3=$ deep and extensive stem lesions, stem girdling that can cause breakage on no more than one branch.

$4=$ deep and extensive girdling stem lesions, causing breakage on more than one branch followed by

extensive wilting.

$5=$ plant killed.

The averages of individual records were classified as follows:

$0-2.5$ resistant; $>2.5=$ susceptible

For counting percentage of pod infection, the following formula was used:

No of infected pods
No of total pods

The results was statistically analysed by using StatGraphics package version 11 and the comparisons between means was performed by using least significance difference (LSD) at $5 \%$ level.

\section{Results}

The results in (Figure 2) show that there were significant differences between treatments in degree of infection. The least disease incidence was with combination of chickpea with faba bean (1.47) followed by combination chickpea with oilseed rape (1.60) and then chickpea accompanied with what (1.98). The results showed that growing chickpea with theses companion crops decreased the disease incidence significantly compared with that of sole chickpea (the control). However, there were no significant differences in the degree of infection between the chickpea and wheat companion and chickpea and oilseed rape combination.

The results also showed that there were no significant effects of these crop combinations on the percentage of pod infection. Nevertheless, the minimum pod infection was occurred in combination of chickpea with oilseed rape which was $2.67 \%$ (Figure 3 ). 


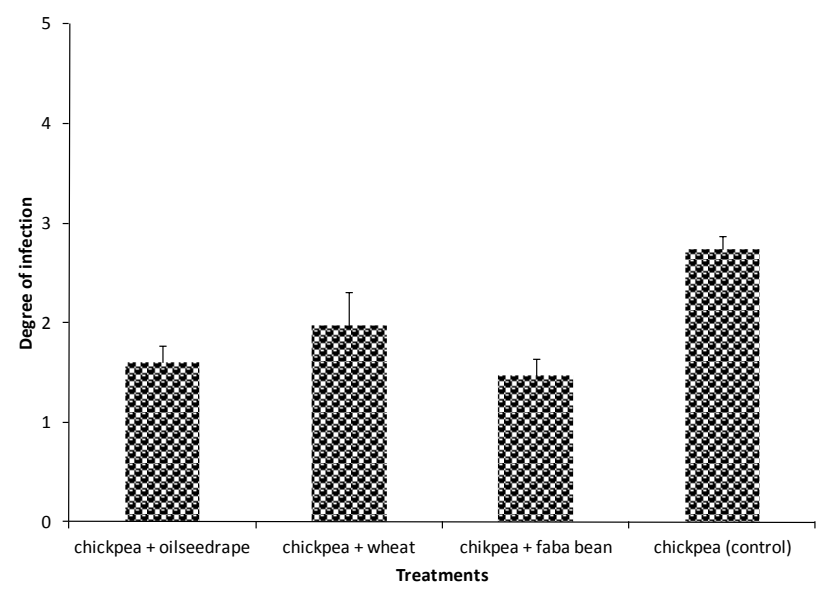

Figure 2 Degree of chickpea blight infection resulted in growing chickpea with companion crops.

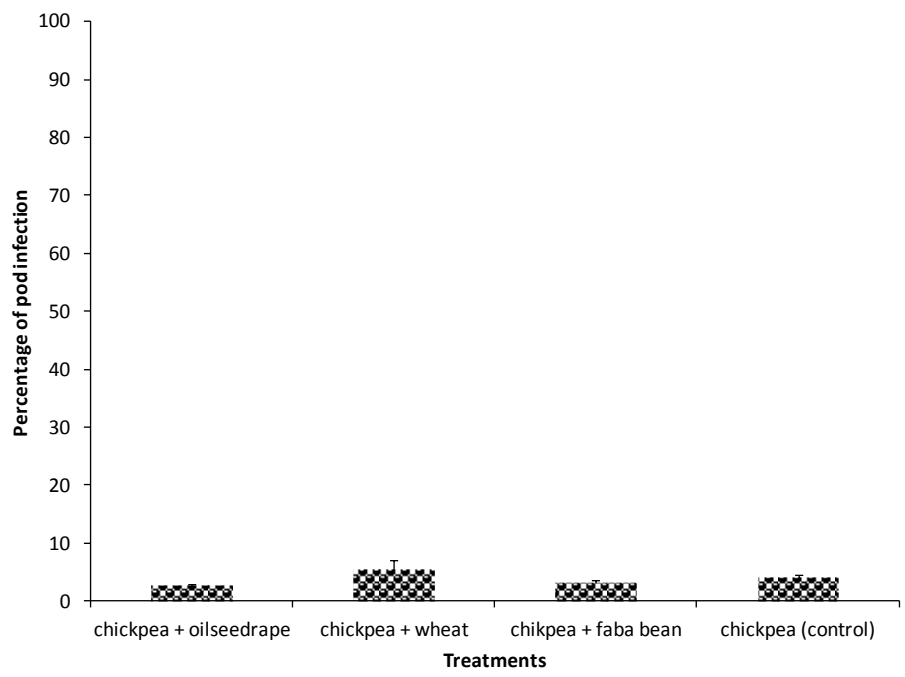

Figure 3 Percentage of chickpea pod infection resulted in growing chickpea with companion crops.

The results of these companion crops showed that both oilseed rape and faba bean didn't affect on the seed yield and have no significant differences with the control (monocrop). However, wheat as a companion crop with chickpea is decreased the yield significantly (Figure 4). On the other hand, the yield in combination chickpea with wheat is also differed significantly with the yield in other combinations.

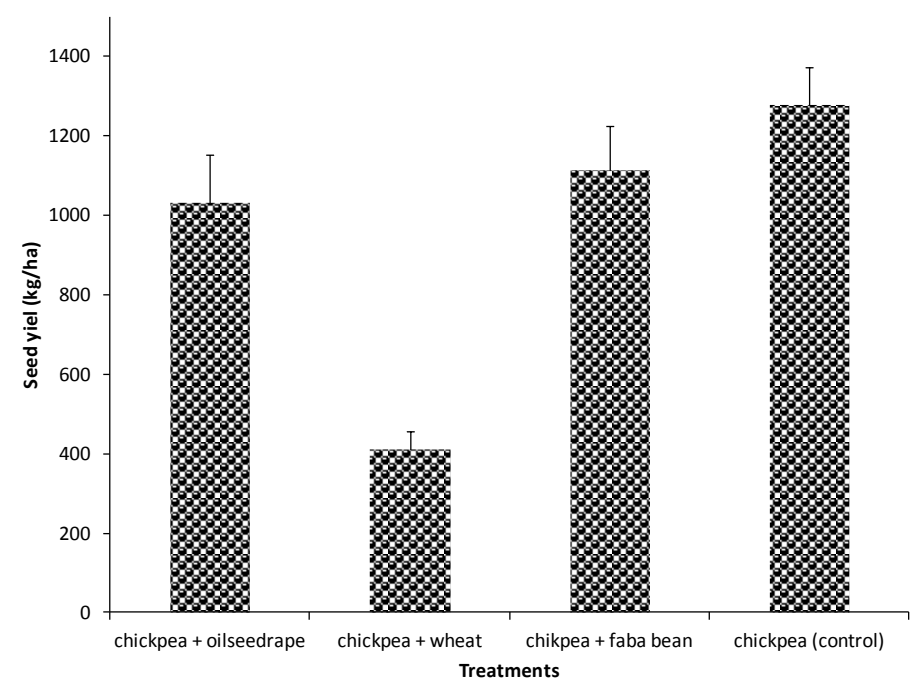

Figure 4 Chickpea seed yield resulted in growing chickpea with companion crops. 
The results of this experiment showed that this system of crop combinations didn't have significant affect on the weight of 100 chickpea seed (Figure 5). However, the highest weight of 100 seed was obtained in combination of chickpea with oilseed rape $(41.13 \mathrm{~g})$ and the lowest weight of 100 seed was in chickpea when combined with wheat $(38.51 \mathrm{~g})$.

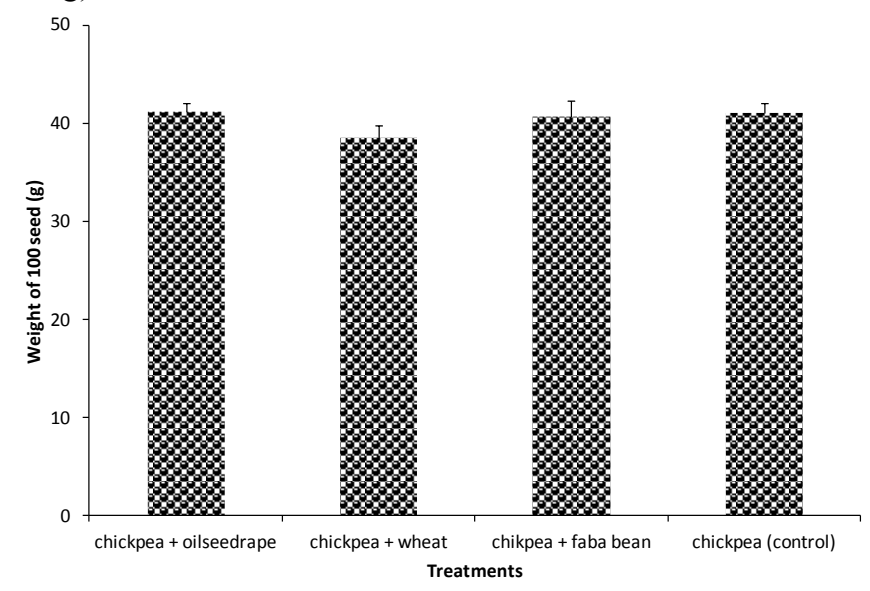

Figure 5 Weight of 100 seed of chickpea plants grown with companion crops.

\section{Discussion}

The results showed that this intercropping system by planting chickpea combined with wheat, oilseed rape, and faba bean was decreased the incidence of chickpea blight to a level lower than susceptible point which is 2.5 on $0-5$ evaluation scale. The degrees of infections were $1.47,1.60$ and 1.98 in the combinations of chickpea with faba bean, oilseed rape and wheat respectively, compared with that of monocrop (2.73). Although this system of crop combinations did not eliminate the chickpea blight but it gave a significant decrease of the disease incidence. The mechanisms that are thought to function to limit the disease development in this intercropping system may be the reduction in production, amount, and effectiveness of the inoculum available for further spread and development within the crop as the proportion of host tissue decreases [12]. The second mechanism involves increasing the space between susceptible hosts within crops, resulting in a greater distance that needs to be travelled by pathogen inoculum which can lead to a reduction in disease development or might be the mechanism involves interception or filtering of pathogen propagules by the non-host component of the intercrop, or some influence on wind or rain-mediated dispersal of pathogen inoculum [13]. One other potential mechanism may occur via an influence on the microenvironment variability within the intercrop as a result of the presence of morphologically different components or an influence via an individual component of the intercrop canopy may produce less favourable microenvironmental conditions, leading to a reduction in disease development [14].

The results of this system showed that, in the combination of wheat with chickpea, a decrease of chickpea seed yield compared with the sole chickpea (fig. 4) but the yield was not affected with other combinations. However, because the disease is seed-borne, this system can be useful for the purpose of diseasefree seeds as a method of certified seed production used for planting without using fungicides. To enhance the yield of chickpea beside the reduction the disease severity, further stripe intercrop distances should be carried out. In this regard and in support to this enhancement, [16] stated that the highest net income was obtained from wheat grown in $100 \mathrm{~cm}$ spaced 4-row stripes combined with 3 rows of chickpea while minimum net return was obtained from 10-row strips combined with 3 rows of chickpea. The results also agree with that of [17] in which inclusion mustard as intercrop reduced the growth parameters of chickpea in intercropping systems.

\section{References}

[1] Hawtin, G. C., and K. B. Singh. (1984). Prospects and potential of winter sowing of chickpea in Mediterranean region. Pages 7-16 in: M.C. Saxena and K. B. Singh, (eds.). Ascochyta blight and winter sowing of chickpeas. Martinus Nijhoff, Dr. W. Junk publ. The Hague.

[2] Reddy, M. V., and K. B. Singh. (1990c). Management of Ascochyta blight of chickpea through integration of host plant tolerance and foliar spraying of chlorothalonil. Indian J. Plant Prot.18: 65-68

[3] Singh, K. B., and M.V. Reddy. (1991). Advances in disease resistance breeding in chickpea. Adv. Agron. 45: 121-222.

[4] Jansen, E. S. Grain legume functions in farming systems. Grain legumes and the environment: how to assess benefits and impacts. International workshop, Zurich, Switzerland, 18 - 19 November (2004).

[5] Hamilton, L. Experiencing with intercropping. Roberts environmental centre, technical papers summery. Claremoint Macckenna College \{online\}, 2003.

[6] Kinane, J. and Michael Lyngkjaer. Intercropping pea with barley reduces Ascochyta blight on pea. Newsletter from Danish Research Centre for Organic Farming. Online: http//www.darcof.dk/enews/mar05/intercrop. html. (2005). 
[7] Sulivan, P. Intercropping principles and production practices (Agronomy systems guide). Appropriate technology transfer for rural areas, National Centre for Appropriate Technology. Fayetteville, AR, USA, \{online\} http//www.attra.org/attrapub/intercrop.html (2001).

[8] Ali, S. S. and Ravi Kumar. Management of root-knot nematodes infesting chickpea through intercropping. Indian Institute for Pulses Research, Kanpur, India. (1999).

[9] Marzani, Q. A. Epiphytotic and control of ascochyta blight of chickpea caused by Ascochyta rabiei (Pass.) Labouse in Erbil Province. MSc. Thesis, Department of Plant Protection, College of Agriculture, Saladin University, Erbil (2003).

[10] Porta-Puglia, A., P. Crino, and C. Mosconi. (1996). Variability in Virulence to Chickpea of an Italian Population of A. rabiei. Plant Disease 80(1): 39-41.

[11] Vir, S. and J. S. Grewal. (1974a). Physiologic specialization in A. rabiei the causal organism of gram blight. Indian Phytopathol. 27(3): 335-360.

[12] Burdon, J. J. Mechanisms of disease control in heterogeneous plant populations - an ecologist's view. P 193 - 200 in: P. R. Scott and A. Bainbridge (eds.) Plant disease epidemiology. Blackwell Science Publishes, Oxford, UK, 1978.

[13] Brown, J. F. Factors affecting the relative ability of strains of fungal pathogens to survive in populations. Journal of Australian institute for Agricultural Sciences. 41: 3-11 (1975).

[14] Boudreau, M.A., and C.C. Mundt. 1997. Ecological approaches to disease control. Pages. 33-62 in: p 33 - 62 in: N. A. Rechcigl and J. E. Rechcgl (eds.) Environmentally safe approaches to crop disease control. CRC press, Boca Raton, Florida, (1997).

[15] Dey, S. K., S. Gurdip, and G. Singh. (1994b). Seed-borne infection of A. rabiei in chickpea and its transmission in plant parts. Phytoparasitica 22(1): 31-37.

[16] Munir, M., M. Saeed and M. Imran. Crop productivity and net returns in wheat-gram intercropping. Pakistan Journal of Agricultural Research 18 (1) (2004)

[17] Tripathi, H. N., Subah, C. and Tripathi, K. Growth and yield of Bengal gram (Cicer arietinum L.) as influenced by mustard raised as intercrop and varying levels of phosphorus. Res. On crops 6 (2): C. S. Azad University of Agriculture and Technology, Kanpur, India (2005). 